\title{
Assessment of Some Dietary Elements and Serum Minerals in Asthmatic Children Attending the Outpatient Clinic of National Nutrition Institute
}

\author{
Azza O.L.Saleh, ${ }^{1}$, Zeinab A. AbdElaal, ${ }^{2}$, Hoda A.Abdelsalam ${ }^{3}$, \\ Wafaa Ismail $^{4}$, Amany A. Abou-Elalla ${ }^{5}$ and Sahar A. Khairy ${ }^{6}$
}

Environmental Medical Sciences ${ }^{1}$, Public Health ${ }^{2}$, Nutrition \& Food Science ${ }^{3}$, Biochemistry ${ }^{4}$, Clinical Pathology ${ }^{5}$, Pediatrics ${ }^{6}$

National Nutrition Institute ${ }^{1,2,3,4,6}$ “Misr University for Science and Technology ${ }^{5}$

\section{ABSTRACT}

sthma is a disease characterized by recurrent attacks of breathlessness and wheezing, which vary in severity and frequency from person to person. Few studies had focused on the relationship between dietary patterns and asthma in children. The study aimed at finding relationship between dietary elements and some serum minerals and asthma in children. A total of 104 children attending the pediatric outpatient clinic of National Nutrition Institute in the age range from 7-10 years were included in the study. Data on nutrition, lifestyle and demography were collected. A Chinese version of the International Study of Asthma and Allergies in Childhood questionnaire was used to detect asthma. Data on nutritional status had been collected using specially designed questionnaires to cover required information on food intake and dietary pattern. Venous blood sample was collected for determination of serum levels of Copper ( $\mathrm{Cu}$ ), Zinc ( $\mathrm{Zn}$ ) and Selenium (Se). The results revealed increased daily intake of energy sources (fats and carbohydrates) and decreased intake of animal proteins and fibers in asthmatic children compared to normal individuals in the study. The daily mineral intake of $(\mathrm{Cu})$ and $(\mathrm{Se})$ was higher and calcium, iodine, sodium, potassium and magnesium intake was lower in asthmatic children as compared to normal ones; while dietary intake of $(\mathrm{Zn})$ and cholesterol was not changed. Anthropometric measurements showed that Body Mass Index (BMI) was significantly higher in asthmatic children than in normal ones. Serum levels of $(\mathrm{Cu}),(\mathrm{Zn})$ and $(\mathrm{Se})$ showed no difference between asthmatic and non-asthmatic individuals. Conclusion: the results suggest that a diet with a high intake of fat and carbohydrate and low intake of animal protein and fiber is associated with increased risk of asthma. Serum levels of $\mathrm{Cu}, \mathrm{Zn}$ and Se showed no difference between asthmatic and normal children. The study also revealed that children with asthma are at higher risk of developing obesity.

Keywords: Asthma, Copper, Zinc, Selenium, Obesity 


\section{INTRODUCTION}

Asthma is a major no communicable disease characterized by recurrent attacks of breathlessness and wheezing. It varies in severity and frequency from person to person. Symptoms may occur several times in a day or week in affected individuals. In some people it may become worse during physical activity or at night. During an asthma attack, the lining of the bronchial tubes swell, causing the airways to narrow and this reduces the flow of air into and out of the lungs (WHO.2017). Lifestyles have been changing rapidly around the globe and the increasing prevalence of asthma symptoms may be related to dietary factors and their complex interactions with genes and environment (Aruuda et al., 2005).

Recently it has been postulated that increased prevalence of asthma is due to changing environmental factors, western lifestyle and eating habits (Pearce and Douwes, 2013).. It has been reported that there is a relationship between the decreased intake of antioxidants and the increased incidence of asthma (Van Oeffelen et al, 2011).

Diet constitutes an important source of nutrients and non-nutrient components with multiple properties that might modulate the risk of asthma and other chronic respiratory diseases in the population. Some components found in foods have been suggested to have a variety of antioxidant, anti-allergic and anti-inflammatory elements, which can have a protective effect against asthma risk (Garcia-Larsen et al., 2016).

Few studies had focused on the relationship between dietary patterns and asthma in children. The Mediterranean diet which is rich in fish, fruits, vegetables, legumes, nuts and cereals, but low in red meat, margarine and junk foods, was the only dietary pattern reported to have a protective effect for asthma in children (CalatayudSáez et al, 2016).

This study examined the effects of some nutrients and the status of some minerals $(\mathrm{Cu}, \mathrm{Zn}$, 
Se) in sera of Egyptian children with allergic asthma attending National Nutrition Institute (N.N.I).

\section{SUBJECTS and METHODS:}

This cross-sectional study was approved by the Research Ethics Committee at National Nutrition Institute (NNI).

\section{Subjects}

The study included 104 children from both sexes who attended the pediatric outpatient clinic of NNIduring August and September 2014. They were randomly selected and they were in the age range from 7-10 years. A face-to-face interview was completed with the attending parents. Informed consent was obtained from the parents of the children in the study. All the children included in the study were subjected to clinical examination in order to confirm or exclude diagnosis of asthma.

\section{Asthma symptoms assessment:} Asthma symptoms were assessed using a Chinese version ofthe International Study of
Asthma and Allergies in Childhood (ISAAC) questionnaire (Asher et al, 1995).Asthma symptoms were defined in the following cases:

a) When there were wheezing attacks more than one time during the last 12 months,

b) When there were $\geq 4$ wheezing attacks in the last 12 months,

c) When sleep was disturbed $\geq 1$ night/per week,

d) When dyslogia occurred due to wheezing in the last 12 months.

e) If there was dry cough at night, apart from a cough associated with a cold or a chest infection during the last 12 months

f) If there was wheezing during or after exercise during the last 12 months

g) If there was a positive answer to the question "Has your child ever had asthma?" 
According to (ISAAC) questionnaire the children involved in the study were divided into normal children with no asthmatic symptoms $(\mathrm{N}=61)$ and asthmatic children $(\mathrm{N}=43)$ showing one or more of the above mentioned symptoms.

Assessment of non-dietary information:

Information on children's characteristics including age, sex, and parental education level, and parental asthma history, number of siblings, and vigorous exercise (that produces sweating) was obtained from parents using a demographic questionnaire. Parental asthma history was defined as a reported history of clinically- diagnosed asthma in one or more parents. Vigorous sweat-inducing exercise was defined as performing exercise that induced sweating more than three times a week.

\section{Dietary assessment:}

Data on nutritional status had been collected using specially designed questionnaires to cover required information on food intake (24-hour recall) and dietary pattern (food frequency) for selected items.

\section{a) Food intake:}

Using the 24 hour recall method, detailed food intake for each eating event was obtained during the previous day to the interview,starting with the first eating event (breakfast) and continued with each eating event subsequently till before sleep. Amounts of foods and beverages consumed were determined by using a dietitian kit of utensils of known weights and volumes.

\section{b) Food frequency method:}

This method was used to obtain a profile of food intake for the study group. A questionnaire was designed to cover the selected food items on daily, weekly and monthly basis. The energy and nutrient content of the last 24 hours were computed using the compiled food composition tables of the National Nutrition Institute., (National Nutrition Institute, 1993). The nutritional value of 
foods and beverages consumed was compared to the recommended dietary allowances "RDAs" of WHO.FAO. /UNU) (Gibson, 1990) and were considered as cut off points for micronutrients.

\section{Anthropometric Measurements:} Body height was measured to the nearest $0.1 \mathrm{~cm}$. Body weight was measured with an electronic scale to the nearest $0.1 \mathrm{~kg}$ with participants wearing light clothes and barefooted. Body mass index was calculated based on the body weight in kilograms divided by the square of the body height in meters. Percentiles according to age and sex were defined in the intervals $\mathrm{p} \geq 95-98$ and $\mathrm{p} \geq 99$ (Wohlfahrt-Veje ,et al,2014).

\section{Laboratory Investigations:}

After an overnight fasting for 12 hours, venous blood sample of $5 \mathrm{ml}$. was collected in plain tubes from each child for determination of serum levels of Copper, zinc and selenium. Serum was rapidly separated by centrifugation.
Separated serum was stored frozen at $-20^{\circ} \mathrm{C}$ until analysis.

- Serum Copper and Zinc were determined by direct colorimetric using kit manufactured by QCA according to (Abe et al, 1989) and (Homsher\& Zak, 1985) respectively.

- Serum Selenium was determined using UVvisible spectrophotometer (Khannaet al, 2010).

\section{Statistical analysis}

Statistical Package for Social Science (SPSS) program version 21.0 was used. Basic data and serum trace elements were summarized as mean and SD. The t-test was used for comparison of independent variables when data were found to be symmetrically distributed, while the non-parametric test (Mann Whitney) was used when data were not symmetrically distributed. One way ANOVA was used for analysis of more than two independent variables followed by the posthoc test for detection of significance. P- 
value was considered significant if $<0.05$. Data on the dietary elements were expressed as median and quartiles.

The independent variablesage, sex and BMI (weight/height in $\mathrm{m} 2$ ) were examined in percentiles according to age and sex defined in the intervals $p \geq 95-98$ and $p$ $\geq 99$.

\section{RESULTS and DISCUSSION}

Table (1) shows the basic data of the studied population. The study included data from 54 boys $(51.9 \%)$ and 50girls (48.1\%) aged 7-10 years. The mean age was $8.6 \pm 1.6$ years. There were more parents with "senior high school education" than either those with "college education" or those with "less than senior high school education". A total of $14.4 \%$ of mothers and $5.8 \%$ of fathers had history of asthma. About 58.7\% of children had one or more siblings. Asthmatic children had a significantly higher BMI (20.8 \pm 7 vs17.3 \pm 5.9$)$ and were more likely to engage in sweating exercise $(32.6 \%$ vs
9.8\%) than normal individuals. Paternal smoking was significantly higher in asthmatic children compared to normal children included in the study.

Despite the recent findings confirming the fact that obesity, by itself might be considered as an inflammatory condition,( Kelly A, Marcus CL 2005) and the generally approved fact that asthma is an inflammatory process, (Busse WW,\&lemanske RF 2001), however Tantisira KG et al (2003) reported that associations between the two conditions are not well understood. Although BMI may not be the best measure of obesity in children, it is widely used and we do not have a more convenient alternative definition (Daniels SR et al 1997). This study confirms the findings of previous studies that a higher BMI is associated with a higher prevalence of wheezy breathing and usual asthma symptoms in children. The findings suggest that a higher BMI in children is associated with a higher prevalence of symptoms that are 
often attributed to asthma, but not with a higher prevalence of asthma. The association between a higher BMI and symptoms of wheeze and cough in children has been observed in previous studies carried by Camargo CA Jr et al (1999). Asthma and obesity often occur together in children, but it is unclear whether children with asthma are at higher risk for onset of obesity or whether obese children develop asthma, or both. The mechanisms that link obesity and asthma may include obesity-influenced lung physiology, such as reductions in pulmonary compliance and limitations in airflow, systemic inflammation, dysfunctions of the sympathetic nervous system, and common genetic factors. Also, children with asthma are known to present with reduced levels of physical activity and may potentially suffer from the side effects of corticosteroid medications that increase their risk of obesity (Zhanghua et al., 2017). However, there is a lack of epidemiological studies that investigate this hypothesis, especially in pediatric population.

Results presented in table (2) revealed the daily intake from ingredients acting as a source of energy (Carbohydrates, fat and protein) and cholesterol. These ingredients were increased in asthmatic patients as compared to non-asthmatic, while animal protein and fiber were decreased in asthmatic patients as compared to non-asthmatic ones. Also there were no changes in cholesterol values in both asthmatics and normal children.

The increase in asthma prevalence is related to environment and lifestyle changes including diet (Devereux 2006). The higher fat intake in asthma subjects compared to normal individuals observed in table (2) agrees with several other reports that have shown an increased total fat intake in severe asthma (Misso et al., 2005). High dietary fat intake has been associated with asthma diagnosis. Margarine intake, a source of trans fatty 
acids, has been related to increased asthma risk (Nagel and Linseisen 2005).

There are a variety of mechanisms by which dietary fat modulates inflammatory responses. Goldman et al., (1983) showed that dietary fat consumption may be able to modify inflammation due to alterations in eicosanoid synthesis, including leukotrienes and prostaglandins. Jolly et al., (1998) explained that fat intake affects cell membrane composition, which can induce changes in gene expression.

\section{Rodri'guez-Rodríguez}

et al., (2010) concluded that increased intakes of saturated fatty acids, myristic and palmitic acids and butter seem to be related to the risk of current asthma in children.

Barros et al., (2011) verified that higher intakes of $n$ 3 polyunsaturated fatty acid (PUFA), alfa linolenic acid (ALA) and saturated fatty acids (SFA) were associated with good asthma control, while the risk for uncontrolled asthma increased with a higher n-6: n-3 PUFA ratio. Bronwyn et al., (2013) suggested that increased fat and reduced fiber intake were related to impairment lung function and airway inflammation. Galisteo et al., (2008) and Maslowski\& Mackay (2011) indicated that dietary fiber (complex plant polysaccharides) as part of carbohydrates adversely affects the makeup of the intestinal microbiota, which leads to less production of immunomodulatory products, in particular short-chain fatty acids (SCFA) and perform antiinflammatory effects due to the production of butyrate and a short-chain fatty acid, by microbiota in the gut that ferments soluble fiber. Butyrate activates the peroxisome proliferator activated receptorwhich then inhibitsnuclear factor kappa-light-chain-enhancer of activated $B$ cells (NFkB) activity; a pro-inflammatory transcription factor. Maslowski et al., (2009) demonstrated that short-chain fatty acids have 
activated a family of $G$ proteincoupled receptors, reducing inflammatory responses in mice models of airway inflammation.

Table (3) indicated the daily minerals intake in asthmatic patients and normal children. Copper, selenium, iron and phosphorus were higher in asthmatic patients than normal ones. Calcium, iodine, sodium, potassium and magnesium intake were decreased in asthmatic individuals as compared to normal ones. The daily intake of zinc was the same value in asthmatic and nonasthmatic subjects.

Burney (1987) said that dietary sodium intake has been shown to be positively related to airway responsiveness. A low sodium diet maintained for 1-2 weeks decreased bronchoconstriction in response to exercise in individuals with asthma. There is no data as to the longer-term effect of a low sodium diet on either the prevalence or severity of asthma or on exercise-induced bronchoconstriction
(Mickleborough and, Fogarty, 2006). High sodium intake may cause hyperpolarization of bronchial smooth muscles, leading to asthma exacerbation (Kim et al., 2009). Pogson et al., (2008) suggested that a low sodium diet has no benefit for lung function and bronchial reactivity.

Gilliland et al., (2002) showed that low dietary potassium intake has also been associated with bronchial hyperactivity and lung function.

Hill et al., (1997) found that high magnesium intake was associated with improvement in symptom scores, though not in objective measures of airflow or airway reactivity, in these stable asthmatic subjects. Magnesium has been shown to be beneficial in several studies, both of acute and stable asthma, although not all studies have confirmed this (Green and Rothrock 1992; Chande and Skoner 1992; Tiffany et al., 1993; Matusiewicz et al., 1994 and Bernstein et al., 1995). 
Zinc deficiency has demonstrated an association with the risk of asthma. Rerksuppaphol and Rerksuppaphol (2016) suggested that zinc supplementation as the adjuvant therapy to the standard treatment during asthma exacerbation resulted in rapid lessening of severity.

A higher intake of selenium may suppress asthma inflammation by saturating glutathione peroxidase. This enzyme catalyzes reduction of peroxides by the antioxidant glutathione, which is thought to play a role in defense against oxidative stress in asthmatic airways (Kelly et al., 1999),

In epidemiologic studies of children and adults, several groups have reported associations between asthma and reduced intake and blood levels of dietary nutrients such as trace elements (selenium, zinc, copper, iron, manganese, and magnesium), some of which have antioxidant properties (Shaheen et al., 2001).
However, supplementation with trace elements as seleniumand magnesium) has not been consistently associated with improved asthma outcomes. A possible explanation for the inconsistencies between epidemiologic and intervention studies is that dietary antioxidants and trace elements primarily influence the development of asthma during a critical time period early in life.

Table (4) revealed that there was no difference in some serummineral levels (copper, zinc and selenium) between asthmatic patients and nonasthmatic individuals. These results were compatible with the study results done by Sagdic et al., (2011) who found that plasma $\mathrm{Cu}$ levels in asthmatic patients were not different from those of the controls. This study revealed no statistically significant difference between patient groups and controls with respect to plasma zinc levels (Sagdic et al., 2011). On the contrary, a study performed on 1 -year-old children revealed that 
higher zinc and copper concentrations in cord blood were associated with increased likelihood of wheezing in 1year-old children. This effect was seen only among children exposed to tobacco smoke at home (Stelmach et al., 2014). Oxidative stress plays a central role in asthma pathogenesis and reduced daily consumption of anti- oxidants is positively correlated with increased risk of asthma. Zinc and Selenium are the main antioxidant elements (Razi et al., 2012). Selenium is an essential element for human health, being a co-factor for enzymes with anti-oxidant activity that protects organisms from oxidative damage. An inadequate intake of such element has been associated with the onset and progression of chronic diseases such as hypertension, diabetes, coronary disease, asthma and cancer. Selenium is subjected to multiregulatory mechanisms .Erythrocytes $\mathrm{Se}$ is a good marker for longer term while plasma Se appears to be a marker of short-term nutritional status (MillanAdame et al., 2012).Serum $\mathrm{Cu}, \mathrm{Zn}$ and selenium were measured in a study done on forty-nine patients, aged 10 to 50 years, with asthma in moderate or severe stages, and 24 healthy controls. Results revealed thatmean serum levels of $\mathrm{Zn}$ and $\mathrm{Se}$ in patients with allergic asthma were lower than in the healthy control group, but the $\mathrm{Cu}$ concentration in sera of patients with allergic asthma was slightly higher than healthy controls (NazilaAriaee et al., 2016) .The discrepancy in the association of serum levels of some minerals and asthma symptoms require more investigations on a greater number of patients.

\section{CONCLUSION}

Children with asthma were at higher risk of developing obesity. In this study we reported that daily intake of carbohydrates, fats, proteins and cholesterol were increased in asthmatic patients, while animal protein and fiber were decreased compared to normal children. Daily minerals intake of copper, 
selenium and phosphorus were higher in asthmatic patients than normal individualsl. Calcium, iodine, sodium, potassium and magnesium intake were decreased in asthmatic individualsin comparison to normal ones. The daily intake of zinc was the same in asthmatic and non-asthmatic ones. Serum copper, zinc and selenium showed no significant difference between asthmatic patients and normal children.

\section{REFERENCES:}

Abe A; Yamashita S and Nom A (1989):

Clin. Chem. 35, No. 4, 552-554.

Arruda LK; Sole D, BaenaCagnani CE, Naspitz Ck. Risk factors for asthma and $\operatorname{atopy}(\mathbf{2 0 0 5})$ :

CurrOpin Allergy Clin Immunol.2005;5:153-9.

Asher MI, Keil U, Anderson HR, Beasley R, Crane J, Martinez F, Mitchell EA,
Pearce N, Sibbald B, Stewart $A W$, et al (1995):

International Study of Asthma and Allergies in Childhood (ISAAC): rationale and methods. EurRespir J. 1995;8:48391.

\section{Barros R, Moreira A, Fonseca}

J, Delgado L, Castel-Branco MG, Haahtela T, Lopes C, Moreira P.(2011):

Dietary intake of $\alpha$ linolenic acid and low ratio of n-6:n-3 PUFA are associated with decreased exhaled NO and improved asthma control. Br J Nutr. 2011 Aug; 106(3):441-50.

Bernstein WK, Khastgir T, Khastgir A, et al.(1995):

Lack of effectiveness of magnesium in chronic stable asthma, Arch Intern Med 1995; 155: 271-276

Bronwyn S. Berthon, Lesley K. Macdonald-Wicks, Peter G. Gibson and Lisa G. WOOD,(2013): 
Investigation of the association between dietary intake, disease severity and airway inflammation in asthma, Respirology 18, 447-454

Burney P (1987):

The causes of asthmadoes salt potentiate bronchial reactivity? $J$. $R$. Soc.Med. 1987; 80: 364-7.

Busse WW and Lemanske RF (2001):

Asthma, $N$ Engl $J$ Med (2001); 344(5):350-62.

Calatayud-Sáez FM, CalatayudMoscoso Del Prado B, Gallego Fernández-Pacheco JG， González-Martín C, Alguacil Merino LF(2016):

Mediterranean diet and childhood asthma, AllergolImmunopathol (Madr). MarApr;44(2):99-105.

Camargo CA Jr, Weiss ST, Zhang S, Willett WC, Speizer FE.(1999):
Prospective study of body mass index, weight change, and risk of adultonset asthma in women, Arch Intern Med; 159(21):2582-8.

Chande VT and Skoner DP (1992):

A trial of nebulised magnesium sulphate to reverse bronchospasm in asthmatic patients, Ann Emerg Med; 21: 11111115

Daniels SR, Khoury PR, Morrison JA.(1997):

The utility of body mass index as a measure of body fatness in children and adolescents: differences by race and gender.Pediatrics 1997; 99(6):804-7

\section{Devereux G (2006):}

The increase in the prevalence of asthma and allergy: food for thought. Nat Rev Immunol 6, 869874. 
Galisteo M, Duarte J, Zarzuelo

A. (2008):

Effects of dietary fibers on disturbances clustered in the metabolic syndrome. J.Nutr.Biochem. 2008; 19: 71-84.

Garcia-Larsen, S. R. Del Giacco, A. Moreira, M. Bonini, D. Charles, T. Reeves, K.-H. Carlsen, T. Haahtela, S. Bonini, J. Fonseca, Agache, N. G. Papadopoulos \& L. Delgado (2016):

Asthma and dietary intake: an overview of systematic reviews. Allergy 71 (2016) 433-442

\section{Gibson R S(1990):}

Principals of nutritional assessment. Oxford University Press. New York, Oxford.

\section{Gilliland FD, Berhane KT, Li} Y-F ,Kim DH, Margolis HG (2002):

Dietary magnesium, potassium, sodium, and children's lung function.
Am. J. Epidemiol. 2002; 155: 125-31.

Goldman DW, Pickett WC and Goetzl EJ (1983):

Human neutrophil chemotactic and degranulating activities of leukotriene B5 (LTB5) derived from eicosapentaenoic acid. Biochem.Biophys. Res. Commun.; 117: 282-8.

Green SM, Rothrock SG.(1992):

Intravenous magnesium for acute asthma: failure to decrease emergency treatment duration or need for hospitalization. Ann Emerg Med 1992; 21: 260-265.

Hill J, Micklewright A, Lewis S, Britton J (1997):

Investigation of the effect of short-term change in dietary magnesium intake in asthma, EurRespir $J$ 1997; 10: 2225-2229 
Homsher, R. and Zak, B.(1985):

Clin. Chem. 31/8, 13101313.

Jolly CA, McMurray DN, Chapkin RS.(1998):

Effect of dietary n-3 fatty acids on interleukin-2 and interleukin-2 receptor alpha expression in activated murine lymphocytes,

Prostaglandins Leukot, Essent. Fatty Acids; 58: 289-93.

Kelly A, Marcus CL.(2005):

Childhood Obesity, Inflammation, and Apnea. What Is the Future for Our Children? Am J RespCrit Care Med; 171(3):202-3.

\section{Kelly FJ, Mudway I, Blomberg} A, Frew A, Sandstrom T.(1999):

Altered lung antioxidant status in patients with mild asthma, Lancet;354:482483.
Khanna R.S., Negi R., Pande D. and Khanna H.D.(2010):

Clinical Significance and Analytical Determination of Trace Amounts of Selenium in Human Blood-

Spectrophotometeric

Technique, The Open Medical Devices Journal, 2, 69-72.

Kim J-H, Ellwood P, Asher MI.(2009):

Diet and asthma: looking back, moving forward. Respir.Res.; 10: 49-55.

\section{Maslowski KM and Mackay CR (2011): \\ Diet, gut microbiota and immune responses. Nat Immunol. 2011 Jan;12(1):5-9.}

Maslowski KM, Vieira AT, Ng A, Kranich J, Sierro F, Yu D, Schilter HC, Rolph MS, Mackay F, Artis D, Xavier RJ, Teixeira MM, Mackay CR (2009):

Regulation of inflammatory responses by 
gut microbiota and chemoattractant receptor GPR43, Nature; 461: 1282-6.

Matusiewicz S, Cusack S, Greening AP and Crompton GK (1994):

A double-blind, placebocontrolled, parallel group study of intravenous magnesium sulphate in acute severe asthma (Abstract)., EurRespir J; 7 (Suppl. 18): 14s.

Mickleborough TD and Fogarty A (2006):

Dietary sodium intake and asthma: an epidemiological and clinical review. Int $J$ ClinPract.; 60(12):161624.

MillanAdame E, Florea D, Saez Peres L, Molina Lopez J, Lopez-Gonzalez B, Perez de la Crus A, Planells del Pozo E.(2012):

Deficient Selenium status of a healthy adult Spanish population, Nutr Hosp.
2012 Mar-Apr;27(2):524-

8.

Misso NLA, BrooksWildhaber J, Ray S, Vally $H$ and Thompson PJ (2005):

Plasma concentrations of dietary and non-dietary antioxidants are low in severe asthma. Eur. Respir. J. 2005; 26: 25764.

\section{Nagel $\mathbf{G}$ and Linseisen $J$} (2005):

Dietary intake of fatty acids, antioxidants and selected food groups and asthma in adults, Eur. J. Clin. Nutr.2005; 59: 8-15.

National Nutrition Institute (NNI)(1993):

Food consumption pattern and nutrients intake among different population groups. Supported by WHO/EMRO.

Nazila Ariaee, Reza Farid, Fahimeh Shabestari, Mohamad Shabestari, 
Farahzad Jabbari Azad (2016):

Trace Elements Status in Sera of Patients with Allergic Asthma. Rep BiochemMol Biol.; 5(1): 20-25.

Pearce N and Douwes J (2013):

Lifestyle changes and children asthma, Indian $J$ Pediatr., 80(Suppl 1):S95S99.

Pogson ZE, Antoniak MD, Pacey SJ, Lewis SA, Britton JR, Fogarty AW. (2008):

Does a low sodium diet improve asthma control? A randomized controlled trial. Am. J. Respir. Crit. Care Med.; 178: 132-8.

RaziCh, Akelma AZ, Akin O, Kocak M, Ozdemir O, Celik A, Kislal FM.(2012):

Hair Zinc and Selenium levels in children with recurrent wheezing. PediatrPulmomol;47(12):

1185-91.
Rerksuppaphol S and Rerksuppaphol L (2016):

Zinc Supplementation in Children with Asthma Exacerbation. Pediatr Rep 9;8(4):6685.

Rodríguez-Rodríguez E, Perea JM, Jiménez AI, RodríguezRodríguez P, López-Sobaler AM, Ortega RM.(2010):

Fat intake and asthma in Spanish schoolchildren, Eur

ClinNutr.;64(10):1065-71.

Sagdic A1, Sener O, Bulucu F, Karadurmus

N, Özel

HE, Yamanel

L, Tasci

C, Naharci I, Ocal R, Aydin A. (2011):

Oxidative stress status and plasma trace elements in patients with asthma or allergic rhinitis. AllergolImmunopathol (Madr).; 39(4):200-5.

Shaheen SO, Sterne JAC, Thompson RL, Songhurst CE, Margetts BM and Burney PGJ (2001): 
Dietary antioxidants and asthma in adults: population based casecontrol study.AmJRespirCritCare Med;164:1823-1828.

Stelmach I, Grzelewski T, Bobrowska-Korzeniowska M, Kopka M, Majak P, Jerzynska J, Stelmach W, PolańskaK,Sobala W, Gromadzińska J, Wąsowicz W, Hanke W.(2014):

The role of zinc, copper, plasma glutathione peroxidase enzyme, and vitamins in the development of allergic diseases in early childhood: The Polish mother and child cohort study. Allergy Asthma Proc.;35(3):227-32.

Tantisira KG, Litonjua AA, Weiss ST and Fuhlbrigge AL(2003):

Association of Body mass with pulmonary function in the Childhood Asthma Management Program. Thorax41-1036(12)58
Tiffany BR, Berk WA, Todd IK and White SR (1993):

Magnesium bolus or infusion fails to improve expiratory flow in acute asthma exacerbations. Chest; 104: 831-834.

Van Oeffelen AA, BEkkers MB, Smit HA, Kerkhof M, Koppelman GH, HavemanNies A, Van der AD, Jansen EH and Wijga AH (2011):

Serum micronutrient concentrations and children asthma: the PIAMA birth cohort study. Pediatr Allergy Immunol.; 22:784-793.

Vojnik C and Hurley LS.(1997):

Abnormal prenatal lung development resulting from maternal zinc deficiency in rats. $J$ Nutr;107:862-872.

WHO (2017):

www.who.int/media center/fact sheets. Updated 2017. 
Wohlfahrt-Veje, C Tinggaard

$\mathrm{J}$, Winther $\mathrm{K}$, Mouritsen $\mathrm{A}$, Hagen CP, Mieritz MG, Renzy-Martin KT, Boas M, Petersen JH and Main KM (2014):

Body fat throughout childhood in 2647 healthy Danish children: agreement of BMI, waist circumference, skinfolds with dual X-ray absorptiometry. Eur. $J$. Clin. Nutr., 68(6), pp.66470.

\section{Zhanghua C, Muhammad T.} S, Tanya L. A, Rima
H,Theresa M. B, Kiros B and Frank D.,G (2017):

Effects of Childhood Asthma on the Development of Obesity among Schoolaged Children .Am J RespirCrit Care Med. Jan 19. 
Assessment of Some Dietary Elements and Serum Minerals in Asthmatic Children Attending the Outpatient Clinic of National Nutrition Institute

Azza OL Saleh; Zeinab A. Abd Elaal; Hoda A Abdelsalam; Wafaa Ismail; Amany A Abou-Elalla and Sahar A Khairy

\section{Table (1): Basic Data of the Study Population}

\begin{tabular}{|c|c|c|c|c|c|}
\hline \multirow{2}{*}{\multicolumn{2}{|c|}{ Variables }} & $\begin{array}{c}\text { Total } \\
\mathrm{N}=104\end{array}$ & $\begin{array}{c}\text { Normal } \\
\mathrm{N}=61\end{array}$ & $\begin{array}{c}\text { Asthmatic } \\
\text { Individuals } \\
\quad \mathrm{N}=43\end{array}$ & \multirow{2}{*}{$\begin{array}{c}\dagger P \\
\text { value }\end{array}$} \\
\hline & & $\begin{array}{c}\mathrm{N}(\%) \text { or } \\
\text { Mean+SD }\end{array}$ & $\begin{array}{l}\mathrm{N}(\%) \text { or } \\
\text { Mean+SD }\end{array}$ & $\begin{array}{c}\mathrm{N}(\%) \text { or } \\
\text { Mean+SD }\end{array}$ & \\
\hline Age & Years & $8.6 \pm 1.6$ & $8.5 \pm 1.6$ & $8.7 \pm 1.6$ & 0.622 \\
\hline \multirow{2}{*}{ Sex } & Boys & $54(51.9)$ & $29(47.5)$ & $25(58.1)$ & \multirow{2}{*}{0.287} \\
\hline & Girls & $50(48.1)$ & $32(52.5)$ & $18(41.9)$ & \\
\hline BMI & $\mathrm{Kg} / \mathrm{m}^{2}$ & $18.8 \pm 6.5$ & $17.3 \pm 5.9$ & $20.8 \pm 7$ & $0.007 *$ \\
\hline \multirow{2}{*}{$\begin{array}{c}\text { History of Food } \\
\text { allergy }\end{array}$} & Yes & $26(25)$ & $17(27.9)$ & $9(20.9)$ & \multirow{2}{*}{0.421} \\
\hline & No & $78(75)$ & $44(72.1)$ & $34(79.1)$ & \\
\hline \multirow{2}{*}{ No. of siblings } & 1 & $43(41.3)$ & $25(41)$ & $18(41.9)$ & \multirow{2}{*}{0.929} \\
\hline & $>2$ & $61(58.7)$ & $36(59)$ & $25(58.1)$ & \\
\hline \multirow{2}{*}{ Feeding in Infancy } & Breast & $83(79.6)$ & $48(80)$ & $34(79.1)$ & \multirow{2}{*}{0.491} \\
\hline & Breast \& Bottle & $21(19.4)$ & $12(20)$ & $9(18.6)$ & \\
\hline \multirow{2}{*}{ Maternal Smoking } & Yes & $8(7.8)$ & $4(6.6)$ & $4(9.5)$ & \multirow{2}{*}{0.580} \\
\hline & No & $96(92.2)$ & $57(93.4)$ & $39(90.5)$ & \\
\hline \multirow{2}{*}{ Paternal Smoking } & Yes & $41(39.4)$ & $20(32.8)$ & $21(48.8)$ & \multirow{2}{*}{$0.099 *$} \\
\hline & No & $63(60.6)$ & $41(67.2)$ & $22(51.2)$ & \\
\hline \multirow{2}{*}{$\begin{array}{c}\text { Maternal History of } \\
\text { Asthma }\end{array}$} & Yes & $15(14.4)$ & $8(13.1)$ & $7(16.3)$ & \multirow{2}{*}{0.651} \\
\hline & No & $89(85.6)$ & $53(86.9)$ & $36(83.7)$ & \\
\hline \multirow{2}{*}{$\begin{array}{c}\text { Paternal History of } \\
\text { Asthma }\end{array}$} & Yes & $6(5.8)$ & $3(4.90)$ & $3(7.1)$ & \multirow{2}{*}{0.636} \\
\hline & No & $98(94.2)$ & $58(95.1)$ & $40(92.9)$ & \\
\hline \multirow{2}{*}{$\begin{array}{c}\text { Vigorous exercise } \\
>3 / \text { week }\end{array}$} & Yes & $20(19.2)$ & $6(9.8)$ & $14(32.6)$ & \multirow{2}{*}{$0.004 *$} \\
\hline & No & $84(80.8)$ & $55(90.2)$ & $29(67.4)$ & \\
\hline \multirow{4}{*}{ Maternal Education } & Illiterate & $20(19.4)$ & $14(23.3)$ & $6(14)$ & \multirow{4}{*}{0.479} \\
\hline & Primary, Prep & $17(16.5)$ & $11(18.3)$ & $6(14)$ & \\
\hline & $\begin{array}{l}\text { Secondary, } \\
\text { Intermediate }\end{array}$ & $49(47.6)$ & $25(41.7)$ & $24(55.8)$ & \\
\hline & University & $17(16.5)$ & $10(16.7)$ & $7(16.3)$ & \\
\hline \multirow{4}{*}{ Paternal Education } & Illiterate & $16(15.5)$ & $12(20)$ & 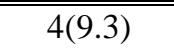 & \multirow{4}{*}{0.411} \\
\hline & Primary, Prep & $16(15.5)$ & $10(16.7)$ & $6(14)$ & \\
\hline & $\begin{array}{l}\text { Secondary, } \\
\text { Intermediate }\end{array}$ & $54(52.4)$ & $28(46.7)$ & $26(60.5)$ & \\
\hline & University & $17(16.5)$ & $11(16.7)$ & $7(16.3)$ & \\
\hline
\end{tabular}

$\uparrow$ Significant differences between boys and girls were assessed using a chi-square test for categorical variables and student's t-test for continuous variables.

*Significant 
Assessment of Some Dietary Elements and Serum Minerals in Asthmatic Children Attending the Outpatient Clinic of National Nutrition Institute

Azza OL Saleh; Zeinab A. Abd Elaal; Hoda A Abdelsalam; Wafaa Ismail; Amany A Abou-Elalla and Sahar A Khairy

Table (2): (Median \& interquartile) of daily protein, fat, carbohydrate and energy intake

\begin{tabular}{|l|c|c|c|c|}
\hline \multirow{2}{*}{ Ingredient } & \multicolumn{2}{|c|}{ Normal subject } & \multicolumn{2}{c|}{ Asthmatic subject } \\
\cline { 2 - 5 } & Median & $\mathbf{2 5}-\mathbf{7 5 \%}$ & Median & $\mathbf{2 5}-\mathbf{7 5 \%}$ \\
\hline Energy (kcal)/day & 1694.0 & $1665.0-1760.0$ & 1714.0 & $1693.0-2145.0$ \\
\hline $\begin{array}{l}\text { Carbohydrates (g) } \\
\text { day }\end{array}$ & 272.0 & $270.0-278.5$ & 285.0 & $270.0-330.0$ \\
\hline $\begin{array}{l}\text { Carbohydrates } \\
\text { calories }\end{array}$ & 1088.0 & $1080.0-1250.0$ & 1140.0 & $1080.0-1320.0$ \\
\hline \% of total Kcal & $\mathbf{6 4 \%}$ & & & \\
\hline Fat (g) /day & 45.0 & $45.0-46.0$ & 50.0 & $45.0-65.0$ \\
\hline Fat calories & 405.0 & $405.0-414.0$ & 450.0 & $405.0-585.0$ \\
\hline \% of total Kcal & $\mathbf{2 4 \%}$ & & $\mathbf{2 6 \%}$ & \\
\hline Total Protein (g)/day & 50.0 & $45.0-57.5$ & 57.0 & $50.0-66.0$ \\
\hline Protein calories & 200.0 & $180.0-230.0$ & 216.0 & $200.0-264.0$ \\
\hline \% of total Kcal & $\mathbf{1 2 \%}$ & & $\mathbf{1 3 \%}$ & \\
\hline Animal protein & 8.0 & $5.0-10.0$ & 7.0 & $5.0-10.0$ \\
Plant protein & 42.0 & $40.0-47.5$ & 50.0 & $45.0-56.0$ \\
\hline Fiber (g) /day & 4.8 & $3.0-7.6$ & 4.3 & $2.6-10.3$ \\
\hline Cholesterol (mg)/day & 198.0 & $50.4-273.0$ & 198.0 & $13.6-287.1$ \\
\hline
\end{tabular}


Table (3): (Median \& interquartile) of daily minerals intake

\begin{tabular}{|l|c|c|c|c|}
\hline \multirow{2}{*}{ Minerals } & \multicolumn{2}{|c|}{ Normal subjects } & \multicolumn{2}{c|}{ Asthmatic subjects } \\
\cline { 2 - 5 } & Median & $\mathbf{2 5 - 7 5 \%}$ & Median & $\mathbf{2 5}-\mathbf{7 5 \%}$ \\
\hline Copper (mg) & 0.500 & $0.395-0.700$ & 0.522 & $0.440-0.710$ \\
\hline Calcium (mg) & 620.0 & $542.0-662.5$ & 612.0 & $575.0-650.0$ \\
\hline Iodine (mg) & 66.0 & $55.5-75.0$ & 60.0 & $52.0-73.0$ \\
\hline Iron (mg) & 6.0 & $5.0-8.0$ & 7.0 & $6.0-8.0$ \\
\hline Selenium ( $\mu$ g) & 16.0 & $14.0-19.0$ & 17.0 & $13.0-19.0$ \\
\hline Zinc (mg) & 4.0 & $3.0-6.0$ & 4.0 & $3.0-6.0$ \\
\hline Sodium (mg) & 722.0 & $622.0-811.5$ & 710.0 & $612.0-800.0$ \\
\hline Potassium(g) & 2.049. & $1.286-2.604$ & 1.812 .8 & $1.356-2.689$ \\
\hline Phosphorus(mg) & 794.2 & $537.9-1220.2$ & 821.2 & $528.1-1344.9$ \\
\hline Magnesium (mg) & 134.2 & $96.2-185.3$ & 131.9 & $93.5-203.5$ \\
\hline
\end{tabular}

\section{Table (4): Mean Serum Level of Some Trace Elements in the Study Group}

\begin{tabular}{|c|c|c|c|c|}
\hline Item & $\begin{array}{c}\text { Normal } \\
\text { Individuals }\end{array}$ & $\begin{array}{c}\text { Asthmatic } \\
\text { Individuals }\end{array}$ & $\begin{array}{c}\mathrm{P} \\
\text { value }\end{array}$ & $\begin{array}{c}\text { Reference } \\
\text { Range }\end{array}$ \\
\hline $\begin{array}{c}\text { Serum Copper } \\
(\mu \mathrm{g} / \mathrm{dl})\end{array}$ & $\begin{array}{c}\mathrm{N}=49 \\
89.9 \pm 36.9\end{array}$ & $\begin{array}{c}\mathrm{N}=34 \\
90 \pm 32.6\end{array}$ & 0.992 & $\begin{array}{c}70-155 \\
\mu \mathrm{g} / \mathrm{dl}\end{array}$ \\
\hline $\begin{array}{l}\text { Serum Zinc } \\
((\mu \mathrm{g} / \mathrm{dl})\end{array}$ & $\begin{array}{c}\mathrm{N}=48 \\
105.3 \pm 26.9\end{array}$ & $\begin{array}{c}\mathrm{N}=33 \\
106.9 \pm 25.1\end{array}$ & 0.780 & $\begin{array}{c}60-110 \\
\mu \mathrm{g} / \mathrm{dl}\end{array}$ \\
\hline $\begin{array}{c}\text { Serum Selenium } \\
\mu \mathrm{g} / \mathrm{dl}\end{array}$ & $\begin{array}{c}\mathrm{N}=46 \\
247.9 \pm 79.8\end{array}$ & $\begin{array}{c}\mathrm{N}=27 \\
271.1 \pm 79.9\end{array}$ & 0.235 & $\begin{array}{c}224.5-239.7 \\
\mu \mathrm{g} / \mathrm{dl}\end{array}$ \\
\hline
\end{tabular}




\section{تقدير بعض العناصر الغذائية و الأملاح المعدنية في مصل

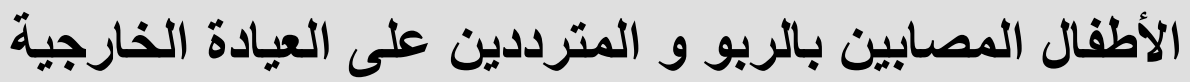 بالمعهد القومي للتغذية}

عزة عمر لطفي صالح'، زينب عباس عبد العال²، هدى عبد الرحمن عبد السلام³، وفاء اسماعيل4، أماني أبو العلا5، سحر خيري

المعهد القومي للتغذية61،23،4، ، جامعة مصر للعلوم و التكنولوجيا5

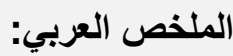

الربو هو مرض يتمبز بنوبات متكررة من ضبق التنفس والصفير، والتي تختلف في شدة

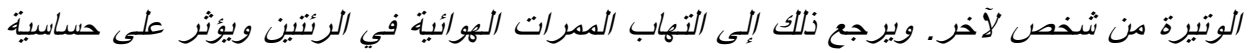

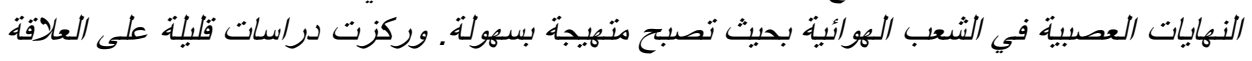

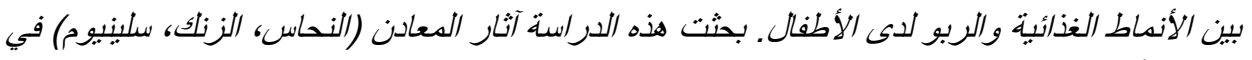

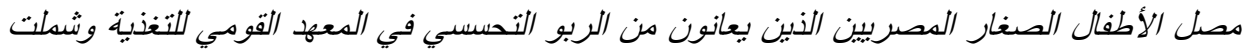

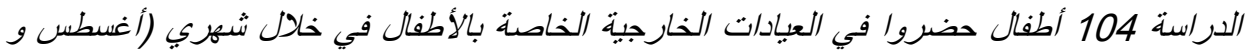

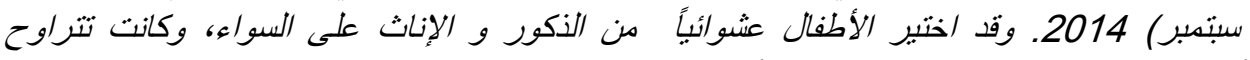

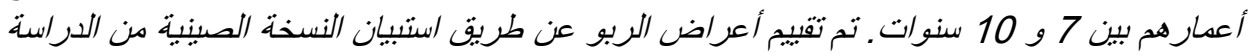

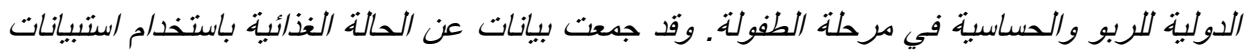

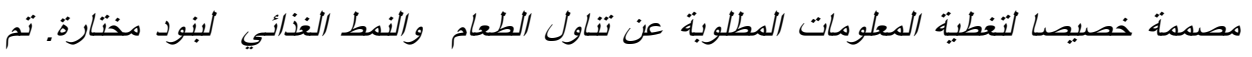

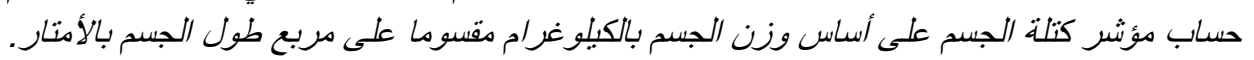

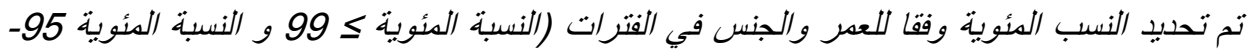
98) بعد صيام اللبيل لددة 12 ساعة، تم جدع عينة دم وريبي (5 مل) من الأطفال لتحديد مستويات

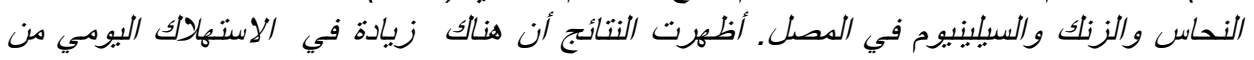

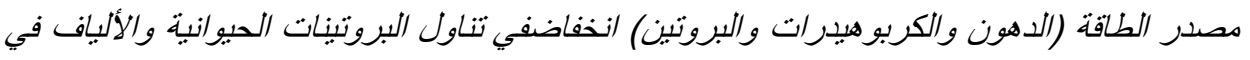

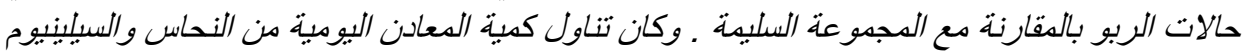

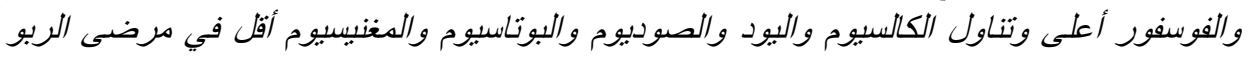

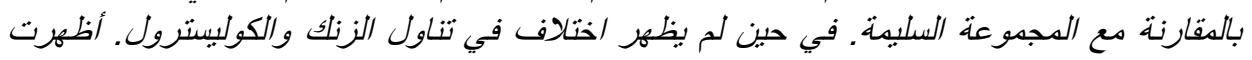

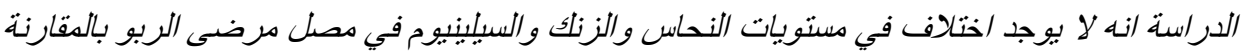

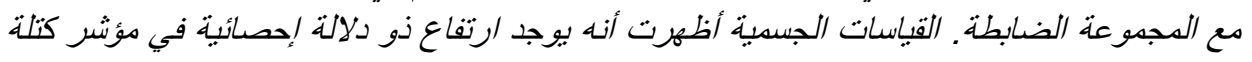
الجسم في مرضى الربو مقارنة بالمجدوعة السلبية. الكلمات الدفتاحية : الربو - النحاس- الزنك- السيلبنيوم- السمنة 